\title{
The Differences in Aggressive Behavior, Deprivation, Well Being and Frustration among the Inmates of Sokoto Prison Nigerian in Relation to their Age and Marital Status.
}

\author{
, Ibrahim Yusuf ${ }^{1}$, Redzuan Ma'aruf, ${ }^{2}$ Hanina Halimatussadiah binti Hamsan, ${ }^{3}$ \\ Nobaya binti Ahmad". \\ Faculty of Human Ecology, Universiti Putra Malaysia. Department of social \& developmental Science.
}

\begin{abstract}
The report examines differences in aggressive behaviour, deprivation, well being and frustration among the inmates in relation to their age and marital status in congested Nigerian prison. However, the work consists of an introduction, age and aggressive behaviour, race and aggressive behaviour, method of information collection and data analysis, and determination. Past studies have shown that males are socialized to believe they should not back down when they are provoked and, if they do, they accept a chance losing their identity, may in turn act upon them to involve in aggressive conduct. An interesting finding by the Benenson (2009) found that males intention to involve in aggressive behaviour is a substance to increase integrity and strength. Moreover, males are more likely than females to have intended to involve in aggressive behaviour negatively when there is conflict, and females intention to involve in aggressive behaviour is for power and influence over others through indirect and verbal aggressive behaviour. According to the 2015 International encyclopedia of the societal and behavioural skills, sex differences in aggression are one of the most rich and most previous findings in psychology. Post meta-analyses in the encyclopedia found males regardless of years engaged in more physical and verbal aggression while small effect for females engaging in more indirect aggression such as rumour spreading or gossiping indirect, tends to increase after age two while physical aggression decreases. At that place was no significant difference in aggression between males and females before two years of age. A possible explanation for this could be that young women make up language skills more quickly than male children, and then they take in more dependable ways of verbalizing their wants and needs. They are more probable to use communication when trying to recover a toy with the words. According to the journal of Aggressive Behaviour, analysis across 9 countries found boy reported more on the use of physical aggression. At the same time no consistent gender differences emerged within relational aggression. It has been found that young women are more likely than sons to use reactive aggression and then retract, but sons are more likely to increase rather than to pull back their aggression after their first response. Studies show girls' aggressive tactics included gossip, ostracism, breaking confidences, and criticism of a victim's clothing, visual aspect, or personality, whereas boys engage in aggression that involves a direct physical and/or verbal assault. This could be due to the fact that the girls' frontal lobes develop earlier than male children, allowing them to self-limit.
\end{abstract}

Key wards:- Race and aggressive behavior, Age and aggressive behavior.

\section{INTRODUCTION}

Gender is a significant element that lead to real aggressive behavior because of the frustration and deprivation (Dempsey \& Storch 2008; Sullivan, Farell \& Kliewer, 2006; Otuadah, 2006; Waasdrop \& Bradshaw, 2011; Juvonem \& Ho, 2008; Macmillan, 2000).

Gender refers to Males and Females.In social psychology, gender is a term used to know how a person does or thinks. Gender is a vital factor to experience various aspects of demeanor. Now, times have changed, the level of females aggressive is more at larger than Males (Sekuku; Rimfat \& Ogbonna, 2003). Moreover, aggressive behavior was linked with facing physical and indirect harassment for inmates, only physical harassment was related to real aggressive behavior (Honglug, 2007). Likewise, females will be more sensitive to social fight and for this reason girls find indirect victimization more worrisome. Moreover, males and females who have been victimized as a outcome of aggressive behavior was found to be a function of males and females, for aggressive behavior like disregarding or rejection friend and revealing secrets aggressive acts are thought to be harmful to inmates (Storch \& Ledley, 2005; Underwood, 2007). Some ingredients may increase males and females intention to involve in aggressive behavior in their lives, such as a poor relation, and lack of connection (Hamel \& Nicholls, 2007; Thaweekoon, 2006).

Understandably, some subjects such as developmental psychology, social psychology, and criminology argued that in some cultures, male children are far bigger in number than girls to have purpose to engage in aggressive 
behavior (Batchelor, 2005; Baillargeon et al, 2007). Interestingly, females of nowadays compared to males are also turning more aggressive, and females intention of aggressive behavior is becoming more unashamed and destructive to the environment (Ringrose, 2006). It is clear to know that females like to engage in group aggressive behavior than males, more physical forms of aggressive behavior and are more likely to be the targets of aggressive behavior well (Crick, Ostrov \& Kawabata, 2007). Similarly, Carbone-Lopez, Esbensen and Brick, (2010) and Cullen, Unnever, Hartman, Turner \& Agnew, (2008) pointed out that males and females have similar influence to get involved in aggressive behavior in the environment due to reactive and proactive functions (Marsee \& Frick, 2007). Another finding by Champion \& Clay (2007) found that females may be less likely than males to retaliate through intention to involve in aggressive behavior and more likely to obtain means to ameliorate the state of affairs.Past surveys have indicated that males are socialized to think they should not back down when they are provoked and, if they answer, they take a chance losing their identity, may in turn act upon them to involve in aggressive behavior (Kalish \& Kimmel, 2010). According to U.S Census Bureau, (2012) asserted that males commit greatly more crime, and are also significantly more likely to be the victims of aggressive behavior than females. Furthermore, males are more probable to have intention to involve in aggressive behavior, which many agents may raise the appeal of the danger of aggressive human action that might contribute to higher layers of intention to involve in aggressive behavior (Gallup, Whit \& Gallup, 2007; Bollmer, Harris \& Milich, 2006). An interesting finding by the Benenson (2009) found that males intention to involve in aggressive behavior is a means to increase unity and force. Moreover, males are more likely than females to have intended to involve in aggressive behavior negatively when there is conflict, and females intention to involve in aggressive behavior is for power and influence over others through indirect and verbal aggressive behavior (Volk, Craig, Boyce \& King, 2006). Furthermore, rule violation and fighting, constantly have great determination that would improve characters which influence males to involve in aggressive behavior (Blackemore \& Coudhury, 2006; Sato, Schulz, Sisk \& Wood, 2008). Whereas females that have been a victim of aggressive behavior indirectly started having sex at an earlier point in their age (Gallup, O'Brien, White \& Wilson, 2009) According to the 2015 International encyclopedia of the social and behavioral skills, sex differences in aggression are one of the most robust and most previous findings in psychology. Past metaanalyses in the encyclopedia found males regardless of age engaged in more physical and verbal aggression while small effect for females engaging in more indirect aggression such as rumor spreading or gossiping. It also found males tend to hire in more unprovoked aggression at a higher frequency than females. This analysis also conforms with the Oxford Handbook of Evolutionary Psychology which reviewed past analysis, which found men to use more verbal and physical aggression with the difference being greater in the physical case. In that respect are more recent findings that evidence that differences in male and female aggression appear at approximately two years of age, though the differences in aggression are more consistent in middle-aged children and adolescence. Tremblay, Japel and Perusse (1999) asserted that physically aggressive behaviors such as kicking, biting and hitting are age-typical expressions of innate and spontaneous responses to biological drives such as anger, thirst, and affiliation. Girls' relational aggression, meaning non-physical or indirect, tends to increase after age two while physical aggression decreases. There was no substantial difference in aggression between males and females before two years of age. A potential explanation for this could be that girls build up language skills more rapidly than boys, so they have more dependable ways of verbalizing their wants and demands. They are more probable to use communication when trying to recover a toy with the speech.. (Gershoff, Elizabeth T. (September 2013)Granting to the journal of Aggressive Behavior, analysis across 9 countries found boy reported more on the role of physical hostility. At the same time no consistent gender differences emerged within relational aggression. It has been found that young women are more probable than sons to use reactive aggression and then retract, but sons are more potential to increase rather than to pull back their aggression after their first response. Studies show girls' aggressive tactics included gossip, ostracism, breaking confidences, and critique of a victim's clothing, visual aspect, or personality, whereas boys engage in aggression that involves a direct physical and/or verbal assault. This could be due to the fact that the girls' frontal lobes develop earlier than male children, letting them to self-limit. (Gershoff, E.T. (2008).

Eelement that shows insignificant differences between male and female aggression is in sports. In mutants, the rate of aggression in both contact and non-contact sports is relatively equal. Since the establishment of Title IX, female sports have increased in competitiveness and importance, which could conduce to the evening of aggression and the "need to gain ground" attitude between both genders. Among sex differences found in adult sports were that females receive a higher scale of indirect hostility while men experience a higher scale of the violation. Another difference found is that men take in up to 20 times higher levels of testosterone than women. (Gray, Peter (Spring 2009)Some surveys suggest that romantic involvement in adolescence decreases aggression in males and females, but decreases at a higher rate in females. Females will seem more suitable to their spouse if they fit in with society and females that are aggressive do not usually fit well in society, they can frequently be seen as antisocial. Female aggression is not considered the norm in society and working against the norm can sometimes prevent one from catching a teammate. Yet, surveys have indicated that an increasing number of 
adult females are getting picked up for domestic violence complaints. In many lands, women now account for a quarter to a third of all domestic violence arrests, up from less than 10 percent a decade ago. The new statistics reflect a reality documented in research: women are perpetrators as well as victims of household violence. All the same, some other equally possible explanation is a event of improved diagnostics: it has become more acceptable for human races to report female domestic violence to the authorities while at the same time actual female domestic violence has not increased at all. This can be the case when men have become less ashamed of reported female violence against them, therefore an increasing number of adult females are arrested, although the factual act of violent women remains the same. (Durrant, Joan; Ensom, Ron (4 2012). September

Also, males in competitive sports are often advised by their coaches not to be in intimate relationships based on the premises that they become more docile and less aggressive during an athletic event. The conditions in which males and females experience aggression are also dissimilar. A study proved that social anxiety and stress was positively correlated with aggression in males, meaning as stress and social anxiety increases so do aggression. Furthermore, a male with higher social skills has a lower rate of aggressive behavior than a male with lower social skills. In females, higher rates of aggression were only correlated with higher rates of strain. Other than biological factors that contribute to aggression, there are physical factors are good. (Gray, Peter (16 May 2011). In humans, there is a seasonal variance in aggression associated with alterations in testosterone. For example, in some primate species, such as rhesus monkeys and baboons, females are more likely to engage in fights around the time of ovulation as well every bit right before menstruation.-If the resolutions were the same in humans as they are in rhesus monkeys and baboons, then the increase in aggressive behaviors during ovulation is explained by the decline in estrogen levels. This makes normal testosterone levels more effectively. Castrated mice and rats exhibit lower levels of aggression. The males castrated as neonates exhibit low levels of aggression, even nate operation of a large number of genes, each of small force, which interact with each other and the environment through evolution and life. (Gray, Peter when given testosterone throughout their development. In general, differences in a continuous phenotype such as aggression are likely to result from the in (Spring 2009). In man, there is sound evidence that the basic human neural architecture underpinning the potential for flexible, aggressive responses is influenced by genes as the well as environment. Conditions of variation between individual people, more than 100 twin and adoption studies, have been held in recent decades examining the genetic basis of aggressive behavior and related constructs such as conduct disorders. According to a metaanalysis published in 2002, approximately $40 \%$ of variance between people is explained by differences in genes, and $60 \%$ of differences in the environment (mainly non-shared environmental influences rather than those that would be portioned out by being raised in concert). Entirely the same, such studies have depended on self-report or notice of others, including parents, which complicates interpretation of the results. The few laboratory-based analyses have not set up significant amounts of individual variance in aggression explicable by genetic variation in the human population. Furthermore, linkage and association studies that try to identify specific genes, for exemplar, that influence neurotransmitter or hormone levels, have more often than not resulted in contradictory findings characterized by failed attempts at reproduction. Rally resulted in contradictory findings characterized by failed attempts at replication (Siever, L. J., LJ (2008).

This is one of the most robust and reliable behavioral sex differences, and it has been found across many different age groups and cultures. Nevertheless, some empirical studies have found the discrepancy in male and female aggression to be more pronounced in childhood and the gender difference in adults to be modest when studied in an observational setting. However, there is evidence that males are quicker to aggression (Frey et al. 2003) and more likely than females to show their aggression physically.-When considering indirect forms of non-violent aggression, such as relational aggression and social rejection, some scientists argue that females can be quite aggressive, although female aggression is rarely expressed physically. An exception is intimate partner violence that occurs among couples who are engaged, married, or in some other kind of intimate relationship. In such instances, some research indicates that adult females are more physically aggressive than adult males, although conflicts are small and men are less probable to be injured than women are.

Although females are less likely than males to initiate physical violence, they can show aggression by using a sort of non-physical means. Exactly which method women use to express aggression is something that changes from culture to civilization. On Bellona Island, a civilization based on male dominance and physical violence, women tends to get into fights with other women more frequently than with humans. Get into conflicts with other women more frequently than with men. When in conflict with males, instead of using physical means, they work up songs mocking the human beings, which diffuse across the island and humiliate him. If a woman wanted to kill a human being, she would either win over her male relatives to drink down him or hire an assassin. Although these two methods involve physical violence, both are forms of indirect aggression, since the aggressor herself avoids getting directly involved or putting herself in immediate physical danger (Akert, R.M., Aronson, E., \& Wilson, T.D. (2010). 
Many scholars maintain that culture is one gene that plays a role in aggression. Tribal or band societies existing before or outside of modern states have sometimes been described as peaceful 'noble savages'. Of modern states have sometimes been described as peaceful 'noble savages'. The !Kung people were distinguished as 'The Harmless People' in a popular work by Elizabeth Marshall Thomas in 1958, while Lawrence Keeley's 1996 War Before Civilization suggested that regular warfare without modern technology was taken by most groups throughout human history, including most Native American tribes. Throughout human history, including most Native American tribes.-Written reports of hunter-gatherers show a range of different companies. In general, aggression, conflict and violence sometimes occur, but direct encounter is generally kept off and conflict is socially managed by a mixture of verbal and non-verbal methods. Different rates of aggression or violence, currently or in the past, within or between groups, have been related to the structuring of social clubs and environmental conditions influencing factors such as resource or property acquisition, land and subsistence techniques, and population change. (quisition, land and subsistence techniques, and population change. (Heinrichs, M; Domes, G (2008)The American psychologist Peter Gray hypothesizes that band hunter-gatherer societies are able to reduce aggression while maintaining relatively peaceful, egalitarian relations between members through several methods, such as fostering a playful spirit in all areas of life, the use of humor to counter the tendency of any single individual to dominate the group, and non-coercive or "indulgent" childraising patterns.the use of humor to counter the tendency of any one person to dominate the group, and noncoercive or "indulgent" child-rearing practices. Gray likens hunter-gatherer bands to social play groups, while emphasizing that such gaming is not frivolous or even easy at all times.-According to Gray, "Social play-that is, play involving more than one player-is necessarily egalitarian. It constantly involves a suspension of hostility and control along with a heightened sensitivity to the needs and desires of the other actors"( Honess, PE; Marin, CM (2006)Joan Durrant at the University of Manitoba writes that a routine of surveys have found physical punishment to be linked with "higher layers of aggression against parents, siblings, peers and spouses", even when containing for other genes.n against parents, siblings, peers and spouses", even when controlling for other factors.-According to Elizabeth Gershoff at the University of Michigan, the more that children are physically punished, the more probable they are as adults to behave violently towards family members, including intimate partners. In rural regions where physical punishment of children is perceived as being more culturally accepted, it is less strongly related to increased aggression; however, physical punishment has been ground to predict some growth in child aggression regardless of culture. While these connections do not prove causality, a number of longitudinal studies suggest that the experience of physical punishment causes a direct causal effect on later aggressive behavior In examining several longitudinal studies that investigated the path from disciplinary spanking to aggression in children from preschool years through adolescence. disciplinary spanking to aggression in children from preschool age through adolescence. Analyzing aggression culturally or politically is complicated by the fact that the label 'aggressive' can itself be used as a means of asserting a judgement from a peculiar point of opinion. Whether a coercive or violent method of social control is perceived as aggression - or as legitimate versus illegitimate aggression - depends on the location of the relevant parties in relation to the social guild of their cultivation. This in turn can relate to constituents such as: norms for organizing actions and dividing resources; what is considered self-defense or provocation; attitudes towards 'outsiders', attitudes towards specific groups such as adult females, the handicapped or the lower condition; the accessibility of alternative dispute resolution strategies; trade interdependence and collective security pacts; fears and impulses; and ultimate goals regarding material and societal outcomes. (Al-Ali, M.M (2011).

Cross-cultural research has found differences in attitudes towards aggression in different civilizations. In one questionnaire study of university students, in addition to men overall justifying some types of aggression more than women, United States respondents justified defensive physical aggression more readily than Japanese or Spanish respondents, whereas Japanese students preferred direct verbal aggression (but not indirect) more than their American and Spanish counterparts. Within American culture, southern men were recorded in a study of on university students to be most affected and to react more aggressively than northerners when randomly insulted after being bumped into, which was theoretically related to a traditional culture of purity in the Southern United States. (Briffa, M. (2010)

A similar sociological concept that may be applied in different cultures is 'face'. Other cultural themes sometimes applied to the field of aggression include versus collectivist styles, which may relate, for exemplar, to whether disputes are responded to with open competition or by accommodating and avoiding disputes. In a study, including 62 countries school principals reported aggressive behavior more often the more individualist, and hence less collectivist, their country's civilization.-Other comparisons made in relation to aggression or war include democratic versus authoritarian political systems and egalitarian versus stratified societies.-The economic system known as capitalism has been seen by some as reliant on the leveraging of human competitiveness and aggression in pursuit of resources and trade, which has been seen in both plus and negative conditions. Man competitiveness and aggression in pursuit of resources and trade, which has been seen in both plus and negative conditions. Attitudes around the social acceptability of particular human activities or objects 
of aggression are also significant elements. This can be highly controversial, as for example in disputes between religions or nation states, for instance, in regard to the Arab-Israeli conflict (Xie, H (2011).

Some students think that behaviors like aggression may be partially learned by observing and imitating the conduct of others. Some students have reasoned out that media may suffer some minor effects on aggression. There is also research questioning this view. For example, a recent long-term outcome study of youth found no long-term relationship between playing violent video games and youth violence or bullying.-I survey indicated there is a smaller effect of violent video games on aggression than has been found with television violence on aggression. This issue is positively associated with the type of game violence and negatively related with time spent playing the games. The writer concluded that insufficient evidence exists to associate video game violence with aggression. (Aureli F., Cords M, Van Schaik CP. (2002).

There has been some links between those prone to violence and their alcohol use. Those who are prone to violence and use alcohol are more likely to carry out violent acts.-Alcohol impairs judgment, making people much less cautious than they usually are (MacDonald et al. 1996). It also disrupts the way information is processed (Bushman 1993, 1997; Bushman \& Cooper 1990).

Pain and discomfort also increase aggression. Even the simple act of placing one's hands in hot water can cause an aggressive response. Hot temperatures have been implicated as a component in a routine of fields. One subject completed in the midst of the civil rights movement found that the riots were more likely on hotter days than cooler ones (Carlsmith \& Anderson 1979). Pupils were found to be more aggressive and irritable after taking a test in a hot classroom (Anderson et al. 1996, Rule, et al. 1987). Drivers in cars without air conditioning were also found to be more likely to honk their horns (Kenrick \& MacFarlane 1986), which is used as a measure of aggression and has shown links to other factors such as generic symbols of aggression or the visibility of other drivers.

\section{AGE AND AGGRESSIVE BEHAVIOR}

Past studies have also found that intention to involve in aggressive behavior among males and females vary with age, with older males showing greater intention to involve in aggressive behavior (Broidy et al, 2003). However studies found that intention to involve in aggressive behavior start between the ages of 11 to 17 (Bjorkqvist, Lagerspets \& Kaukiainen, 1992; Eccles et al, 1993). Moreover, females with age limit 11-17 years old show bias which in turn leads to real aggressive behavior, whereas male bias in intention of aggressive behavior is higher in age between 18 -30 years old (Archer, 2004). So age is an influential characteristic that contribute to real aggressive behavior (Petras, Masyn \& lalongo, 2011; Bradshow, Schaeffer, Petra and lalongo, 2010).

\section{RACE AND AGGRESSIVE BEHAVIOR}

Raceway has been argued to contribute to aggressive behavior among the inmates (Skiba, Shure \& Williams, 20012). Racial discrimination can lead to intention to involve in aggressive behavior among peoples, and black peoples have more intention to involve in aggressive behavior when compared to white peoples (Bogart \& Laura, 2013). Moreover, racial differences in causes for suspension for threatening someone may lead to aggressive behavior among the peoples (Gregory \& Weinstein, 2008). Inquiry reveals that experiences of racial discrimination and racial bias are psychosocial stressors globally that adversely effect peoples' intention to engage in aggressive behavior (Pascoe \& Richman, 2009; Williams \& Muhammad, 2009; Coker et al, 2009; Paradies, 2006; Pascoe \& Richman, 2009; Neighbor \& Jackson, 2008).

Gee, Ro, Shariff- Marco \& Chae, (2009) and Leong \& Okazaki, (2009) found that Asian Americans peoples have no ace in history as a target of racial discrimination which in turn lead to aggressive behavior. In addition, discrimination of race may hold different meaning between people. Similarly, Rosenbloom \& Way (2004) found that Asian Americans people always show racial discrimination than people from other race group which may too lead to aggressive behavior. Today, most negative behavior in the varieties of racism against other people includes hate crimes, which could be seen as prejudiced motivated crimes that call for harassment, assault, damage to property and verbal abuse that may in turn lead to aggressive behavior (Umemoto, 2000). Some evidence also suggests that more than half of first and second generation Chinese American people in two quantitative studies completed in Boston and New York shows that beaten someone, being victim as a course of harassment increase aggressive behavior (Qin, Way \& Mukherjee). Moreover, a survey conducted in the UK and USA among Muslims by Rippy \& Newman (2006) and Laird, Pettit, Dodge \& Bates, (2005) set up a relationship between discrimination of race, with increased people's intention to involve in aggressive behavior among black and white peoples, and argues that black kids experience a higher degree of intention to engage in aggressive conduct. Aggressive behavior varies on the basis of race, and studies reported that African Americans were less probable to be victimized and more likely to be perpetrators when compared to other racial groups (Wang, Lannotti \& Tonja, 2009). Moreover, peoples of minority social groups may have as in size experienced racial discrimination which may contribute to aggressive behavior compared with ethnic majority 
religious affiliation (Hong \& Espelage, 2012; Larochette, Murphy \& Craig, 2010). Coherent with this, characteristics individuals with differences in ethnicities and race may lead to aggressive behavior (Petras, Masyn \& Lalongo, 2011; Bradshaw, Schaeffer, Petra \& Lalongo, 2010). Clearly, strong group affiliations and bias with regard to race have been found among people intention to involve in aggressive behavior (Aboud, 1988). Surveys conducted in the united states by Peskin, Tortolero \& Markham (2006) and Spriggs Lannotti, Nansel \& Haynie (2007) establish that race receives a significant relationship with peoples intention to involve in aggressive behavior and peoples from many racial groups, like Hispanic-American, African-American have been found at all to be at a bigger danger of being victims of aggressive behavior compare to other people from other European nations.

\section{RESEARCH METHODOLOGY}

In this chapter, an attempt is created to explain how data is going to be plucked up from the field. Considering the nature of the survey, quantitative method seems to be relevant. Therefore the main concern of this section a research plan, brief history of the subject, region, description of the population, sample and sampling techniques, instrument for data accumulation, and method of data analysis.

\section{RESEARCH DESIGN}

This study was approached by a quantitative research method which employed survey research design. According to Creswell (1994) quantitative study is the investigation of the human social problem based on testing of theory composed of variables which require to measure with numbers and analyzed with statistical method in order to achieve a logical end to assure whether expected prediction of theory hold true or not. This quantitative research employed a cross-sectional and survey as well as correlation study. The correlation method used to encounter out the nature of relationships between variables. Two or more variable measures drawn from the same group of themes were related by correlation research design (Salkind, 2006). In this inquiry, sketch design was used because survey involved using a questionnaire to find out the relationship between deprivation, well being, frustration and aggressive behavior among the inmates in Nigerian prisons. According to Barusch \& Wilby (2010) and Duan, Brown \& Keller, (2010) survey design is a type of descriptive technique that takes a set of scientific and organized techniques for keying out, explaining phenomena and exploring attitudes and behaviors through questionnaires for the purpose of generalizing the findings to a larger population of interest. Survey design has been selected because it helps together and identify the features of a population for a valid outcome (Fraenkel, Wallan \& Hyun, 2012).

The reason why quantitative research was required, because the focal point is to plan or establish the use of tests, scales and statistical methods to collect and analyze numerical information, objectivity, validity and reliability for the intent of identifying and explicating the issues that contribute to the explanation of deprivation, well being, frustration and aggressive behavior. It has been practiced in many social sciences (Burnard, Morrison \& Gluyas, 2011).Survey design has been chosen because is among the best method of collecting information from the prison inmates, about aggressive behavior (Ignou, 2007; Shaughnessy, Zechmeister \& Zechmeister, 2009).

\section{LOCATION OF THE STUDY}

The study was carried out in Sokoto State central prison in Nigerian. The prison was built in 1908 right in the Marina area of Sokoto State during the period of British colonial in Nigeria. Since then the prison has passed through developmental levels, the country felt that from regional two federal levels. It should be mentioned, nevertheless, that it was Prison Act 1960 that effectively brought all the Nigerian prisons under the legal power of the federal government. However, the researcher selected Sokoto State Central prison, Zamfara state and Kebbi state central prison in the northwestern constituent of the Nigeria, but the controller general of the Nigerian prison service only approved Sokoto state central Prison because of the crisis of Bokoharam that affect the system in particular and the social institution in general. Sokoto Central Prison as proposed selected prison in Northwestern Nigeria is one of the 234 prisons in the country (Nigeria) with the total capacity of 576 inmates. Population of sokoto central inmates was 640 and 164 waders. The population is divided into categories or section based on awaiting trail and convicted.

Moreover, Sokoto central prison has different department, which include, welfare unit, security instructor, central admin section, sewing department, carpentry department, wandering department. These sections work inter party in order to maintain and achieve the main objective of the total creation.

Sokoto central prison was selected and approved by the Nigerian Government in order to render the remaining prisons in Nigeria since the bunk is all the same and under one control. Some other reason is that Sokoto central prison is one of the biggest and a central prison in the zone which comprises of different inmates from different States. Lastly, there are issues of deprivation, well being, frustration and aggressive behaviour among the convicts, which lead to the retardation of human development. 
Map of Sokoto State

\section{POPULATION OF THE STUDY}

The subject population for this study are the inmates males only of the Sokoto central prison, both the awaiting trial and convicted were inclusive. From aged about 18-45 and 45 for the above years. These were not mentioned are excluded. The female was kept out because they are very few in numbers and the stratum of their aggressive behavior is minimal. Population is defined as all members of any well defined people, event and it also the entire group of interest to the researcher, the group to which researcher would like the answers to be generalized (Ary, Jacobs \& Sorensen, 2009)

\section{SAMPLING SIZE}

Sample refers to the portion, a fraction or part of the population that will select for the purpose of the study that represent the entire population (Avana et al 2004). Graziano \& Raulin, (2000) as well as Neumann, (2006) indicate that the sample size in survey depends on the research design, the kind of data analysis employed, how accurate the sample has to be, and various other factors concerning the exact research. Finding a suitable sample size is really essential, since a heavy act of sample size determinants might also constrained by cost; in terms of money, time administrative support, stress, resources and the number of researchers (Borg \& Gall, 1979; Cohen, et al., 2007). A small samples may lead to wrong results (Schaffer, 2007). However, Sekeran (1983) suggested that as a normal thumb, more sample size of about 350 to 500 could be effective. Similarly, Tabachnick \& Fidell, (1996) given the accompanying template for sample size: 50 as very poor; 100 as poor, 200 as fair, 300 as well, good, 500 as very good and 1000 as excellent. According to Cohen, Manion \& Morrison, (2007) sampling is a minor subset of observations selected to characterize and generalize researcher's findings about the intact population of interests. There are several procedures that determine the sample size of the research. For the purpose of this research, Cochran's (1977) method was used in order to produce precise needed sample size related to the population. Cochran's (1977) formula uses two much more important factors:

1. The inaccuracy the researcher is eager to accept.

2. The alpha level of accepting the risk, the researcher is willing to receive that the true border of error goes above the acceptable margin of error.

3. $t^{2}=1.96$ or 2 as maintained by Bartlett; (2001), the $t$ value for the alpha 0.5 and a population of $>_{-} 60=2$

$t^{2}=$ risk willing to assume that actual margin of error may exceed acceptable margin of error.

$\mathrm{P}=0.5$ (according to Cochran's (1977) recommended that, the researcher should use 0.50 as an estimated of the population ratio.

$\mathrm{P}=$ estimates the ratio of the elements in the population of the categories of interest (estimated variance in the population).

$\mathrm{Q}=1-\mathrm{p} \quad \mathrm{q}=1-0.5=0.5$

$\mathrm{P} \mathrm{q}=$ estimated variance in population $(50 \%$ chance $=0.5)$.

$\mathrm{D}=95 \%$ (0.5) Bartlett et al (2001) asserted that, an alpha level 0.5 is acceptable for many research.

$\mathrm{D}=$ acceptable margin of error for the proportion being estimated $=0.05$ (the error researcher is willing to have a bun in the oven).

$\mathrm{N}=$ population size.

The Cochran's (1977) Sample formula is shown to a lower place:

$$
\begin{gathered}
n_{1}=\frac{n_{0}}{1+\frac{n_{0}}{N}} \\
\mathrm{n}=\text { Sample size } \\
\text { Where } n_{0}=\frac{(c i)^{2}(p)^{2}}{(d)^{2}} \\
c_{i}=95 \% \text { confidence interval } \\
p=50 \%=0.5 \text { assumed proportions } \\
d=0.05 \alpha \text { level } \\
\mathrm{N}=\text { total population } \\
n_{0}=\frac{(2)^{2}(0.5)^{2}}{(0.05)^{2}} \\
=\frac{3.84 \times 0.25}{0.0025} \\
n_{0}=384 \\
\mathrm{n}_{1}=\frac{384}{1+\frac{384}{640}} \\
\mathrm{n}_{1}=\frac{384}{1+0.6}
\end{gathered}
$$




$$
\mathrm{n}_{1}=\frac{384}{1.6}=240
$$

Additional $25 \%$ to avoid drop out based on (). To calculate the $25 \%$ here is the procedure. $\frac{240}{100} \times 25=60$. Nagoya et al, (2005) In this study, the sample size is 300 respondents.

\section{Sampling Technique}

According to Gravette and Forzano (2006) that, any population of the survey which comprises of a number of subs-groups, especially gender, age group and class are expected to show their dissimilarities when studied. Thus, in this work, the researcher used probability sampling technique in which the population sample for the research was drawn through stratified simple random sampling. Rubin and Rubin (2005) assert that, on the technique of picking out samples, rather than selecting large samples representative is enough to make generalizations as in the case of quantitative study. According to Cohen (1988) selecting a representative sample of a population is better than obtaining a large, but biased sample that would contribute to an erroneous opinion in the population.

IX. DATA ANALYSIS

Table 1: ANOVA test of significance for regression coefficients

\begin{tabular}{|ll|r|r|r|r|r|}
\hline Model & Sum of Squares & \multicolumn{1}{c|}{ df } & Mean Square & \multicolumn{1}{c|}{ F } & Sig. \\
\hline & Regression & 4286.472 & 7 & 857.294 & 12.649 & $.000^{\mathrm{b}}$ \\
Residual & 19858.270 & 293 & 67.776 & & \\
Total & 24144.742 & 300 & & & \\
\hline
\end{tabular}

a. Dependent Variable: Aggressive Behavior

The ANOVA test tests the following hypothesis

$H_{0}: \hat{Y}=\beta_{0}+e_{i}$

$H_{a}: \hat{Y}_{i}=\beta_{0}+\beta_{1} X_{1}+\beta_{2} X_{2}+\beta_{3} X_{3}+\beta_{4} X_{4}+\beta_{5} X_{5}+e_{i}$

Where

$\widehat{Y}=$ Aggressive behavior

$X_{1}=$ Deprivation

$X_{2}=$ Prisoners Well Being

$X_{3}=$ Relationship between the Inmates and Waders

$X_{4}=$ Number in one room

$X_{5}=$ Status

The result of ANOVA table shows that the whole regression predictors in simultaneously predicting the aggressive behavior are statistically significant.

The mathematical regression model is

$\hat{Y}_{i}=29.838+1.431 X_{1}-0.047 X_{2}-0.154 X_{3}+0.465 X_{4}-7.212 X_{5}+e_{i}$

TABLE 2: Significant Difference in Aggressive Behavior based on Dichotomous variables

\begin{tabular}{|l|l|l|l|l|l|}
\hline Variables & $\mathrm{N}$ & Mean & SD & T & Sig. \\
\hline Sex Male & 300 & 75.9216 & 8.96421 & 3.291 & 0.001 \\
\hline $\begin{array}{c}\text { Marital status } \\
\text { Single } \\
\text { Married }\end{array}$ & 97 & 78.0417 & 8.74422 & 2.054 & 0.041 \\
\hline $\begin{array}{c}\text { Status } \\
\text { Awaiting trial } \\
\text { Convicted }\end{array}$ & 160 & 75.7635 & 9.04955 & & \\
\hline
\end{tabular}

Marital Status: The result shows that there is significant difference between the levels of aggressiveness with respect to marital status. It revealed that people who are single are more aggressive than those have married.

Status: The result shows that there is significant difference between the levels of aggressiveness of those that are waiting for trial and those that have been convicted. It revealed that those that are waiting for trial are more aggressive than those that have been convicted. 
Table 3: Descriptive measures on Age groups

\begin{tabular}{|l|r|r|r|}
\hline Age Group & \multicolumn{1}{|c|}{ N } & Mean & \multicolumn{1}{c|}{ Std. Deviation } \\
& & & \\
& & & \\
\hline $18-25$ & 36 & 79.8000 & 7.27930 \\
$26-35$ & 122 & 78.2131 & 8.48550 \\
$36-45$ & 81 & 75.3704 & 9.25263 \\
$>45$ & 61 & 72.6557 & 9.16312 \\
Total & 300 & 76.4950 & 9.00126 \\
\hline
\end{tabular}

Table 4: Significant Difference in Aggressive Behavior based on the Age group

\begin{tabular}{|l|r|r|r|r|r|}
\hline & Sum of Squares & \multicolumn{1}{|c|}{ Df } & Mean Square & F & \multicolumn{1}{c|}{ Sig. } \\
\hline Between Groups & 1744.024 & 5 & 581.341 & 7.656 & .000 \\
Within Groups & 22400.718 & 295 & 75.935 & & \\
Total & 24144.742 & 300 & & & \\
\hline
\end{tabular}

The results showed that there is significant difference between the levels of aggressiveness with respect to the classes of age groups.

Table 5: LSD test for Mean Difference among Age groups

\begin{tabular}{|ll|r|r|r|}
\hline (I) Age & (J) Age & $\begin{array}{r}\text { Mean Difference } \\
\text { (I-J) }\end{array}$ & Std. Error & Sig. \\
& & & & \\
\hline \multirow{3}{*}{$18-25$} & $26-35$ & 1.58689 & 1.67092 & .343 \\
& $36-45$ & $4.42963^{*}$ & 1.76268 & .013 \\
& $>45$ & $7.14426^{*}$ & 1.84781 & .000 \\
& $18-25$ & -1.58689 & 1.67092 & .343 \\
$26-35$ & $36-45$ & $2.84274^{*}$ & 1.24895 & .024 \\
& $>45$ & $5.55738^{*}$ & 1.36647 & .000 \\
& $18-25$ & $-4.42963^{*}$ & 1.76268 & .013 \\
$36-45$ & $26-35$ & $-2.84274^{*}$ & 1.24895 & .024 \\
& $>45$ & 2.71463 & 1.47726 & .067 \\
& $18-25$ & $-7.14426^{*}$ & 1.84781 & .000 \\
$>45$ & $26-35$ & $-5.55738^{*}$ & 1.36647 & .000 \\
& $36-45$ & -2.71463 & 1.47726 & .067 \\
\hline
\end{tabular}

The result of LSD shows that prisoners within the age bracket of 18-25 and 26-35 are more aggressive than those in age bracket of 36-45 and those that are older than 45 years. The result also revealed that there is no significant difference between the levels of aggressiveness of prisoners of age bracket 18-25 and 26-35 and also between the age bracket of $36-45$ and those above 45 years.

Table 6: Descriptive measures on Tribe

\begin{tabular}{|l|r|r|r|}
\hline & $\mathrm{N}$ & Mean & \multicolumn{1}{c|}{ Std. Deviation } \\
\hline Yoruba & & & \\
Igbo & 49 & 78.6667 & 8.46604 \\
Hausa & 44 & 77.3182 & 6.81234 \\
Others & 196 & 75.7755 & 9.31724 \\
\hline
\end{tabular}

Table 7: Significant Difference in Aggressive Behavior based on Tribe

\begin{tabular}{|l|c|c|c|c|c|}
\hline & Sum of Squares & Df & Mean Square & F & Sig. \\
\hline \multicolumn{5}{|c|}{ www.iosrjournals.org } \\
\hline DOI: $10.9790 / 0837-2108021326$
\end{tabular}




\begin{tabular}{|l|r|r|r|r|r|}
\hline Between Groups & 357.681 & 5 & 119.227 & 1.479 & 0.220 \\
Within Groups & 23787.062 & 295 & 80.634 & & \\
Total & 24144.742 & 300 & & & \\
\hline
\end{tabular}

The results showed that there is no significant difference between the levels of aggressiveness of the prisoners with respect to their tribe. This implies that the aggressiveness among the prisoners is not influenced by their culture.

\section{CONCLUTION}

Aggressive behaviour defers base on age, matrimonial status, gender and etc. Similar effects were found by Catherine Taylor at Tulane University in 2010.-Family violence researcher Murray A. Straus argues, "There are many reasons this evidence has been ignored. Single of the Straus argues, "There are many reasons this evidence has been ignored. iolent discipline, and is, therefore, sometimes necessary, despite the risk of harmful side effects

\section{REFERENCES}

[1] Adamson, D.J.; Edwards, D.H.; Issa, F.A. (1999). "Dominance Hierarchy Formation in Juvenile Crayfish Procambarus Clarkii". Journal of Experimental Biology 202 (24): 3497-3506. PMID 10574728.

[2] Adelola, Israel and Atere, Adewole Akin (2003) Captives, Captors and Society - A Sociological Inquiry into the Adjustment Mechanisms of Prison Inmates in Nigeria. Ibadan; Hure Prints.

[3] Akert, M. Robin, Aronson, E., and Wilson, D.T. "Social Psychology", 5th Edition. Pearson Education, Inc. 2005

[4] Akert, R.M., Aronson, E., \& Wilson, T.D. (2010). Social Psychology (7th ed.). Upper Saddle River, NJ: Prentice Hall.

[5] Al-Ali, M.M (2011). "Social anxiety in relation to social skills, aggression, and stress among male and female commercial institute students". Education 132 (2): 351-61.

[6] Alexander, Michelle (2010). The New Jim Crow: Mass Incarceration in the Age of Colorblindness. The New Press. pp. 180-181. ISBN 9781595581037.

[7] Alexander, Michelle (2010). The New Jim Crow: Mass Incarceration in the Age of Colorblindness. The New Press. ISBN 9781595581037.

[8] Allen, Danielle S. "Punishment in Ancient Athens". Harvard University, Center for Hellenic Studies.

[9] Al-Rodhan, Nayef R.F., "emotional amoral egoism:" A Neurophilosophical Theory of Human Nature and its Universal Security Implications, LIT 2008.

[10] Al-Rodhan, Nayef R.F., Sustainable History and the Dignity of Man: A Philosophy of History and Civilisational Triumph, Berlin, LIT, 2009.

[11] American Academy of Pediatrics (2011) Ages \& Stages: Aggressive Behavior HealthChildren.org, retrieved January 2012.

[12] Amjad, N.; Wood, A.M. (2009). "Identifying and changing the normative beliefs about aggression which lead young Muslim adults to join extremist anti-Semitic groups in Pakistan" (PDF). Aggressive Behavior 35 (6): 514-519. doi:10.1002/ab.20325. PMID 19790255.

[13] Buss, D.M. (2005). The murderer next door: Why the mind Is designed to kill. New Y3ork: Penguin Press.

[14] Cant, MA; Llop, J; Field, J (2006). "Individual variation in social aggression and the probability of inheritance: theory and a field test". American Naturalist 167 (6): 837-852. doi:10.1086/503445.

[15] Carceral, K.C. (2006). Prison, Inc: A Convict Exposes Life Inside a Private Prison. NYU Press. p. 11. ISBN 978-0-8147-9955-0.

[16] Card, N.A.; Stucky, B.D.; Sawalani, G.M.; Little, T.D. (2008). "Direct and indirect aggression during childhood and adolescence: A meta-analytic review of gender differences, intercorrelations, and relations to maladjustment". Child Development 79 (5): 1185-1229. doi:10.1111/j.1467-8624.2008.01184.x. PMID 18826521.

[17] Carlson, Peter M., ed. (2013). "Correctional Academic, Career, and Reentry Education". Prison and Jail Administration: Practice and Theory. Jones \& Bartlett. p. 108. ISBN 9781449653064.

[18] Carlson, Peter M., ed. (2013). "Inmate Classification". Prison and Jail Administration: Practice and Theory. Jones \& Bartlett. ISBN 9781449653064.

[19] Castellano, T. C. \& Soderstrom, I. R. (1997) 'Self-Esteem, Depression, and Anxiety

[20] Castle, T.; Hensley, C. (2002). "Serial Killers with Military Experience: Applying Learning Theory to Serial Murder". International Journal of Offender Therapy and Comparative Criminology 46 (4): 453-65. doi:10.1177/0306624X02464007. PMID 12150084.

[21] Christopher J. Ferguson, (2010) "Video Games and Youth Violence: A Prospective Analysis in Adolescents", Journal of Youth and Adolescence. 
[22] Clear, Todd R. (2007). "Incarceration and crime". Imprisoning Communities: How Mass Incarceration Makes Disadvantaged Neighborhoods Worse. Oxford University Press. ISBN 9780199885558.

[23] Clear, Todd R. (2007). Imprisoning Communities: How Mass Incarceration Makes Disadvantaged Neighborhoods Worse. Oxford University Press. ISBN 9780199885558.

[24] Cohn, Scott (2011-10-18). "Billions Behind Bars: Inside America's Prison Industry". CNBC.

[25] Coker, Donna (2002). "Transformative Justice: Anti-Subordination Process in Cases of Domestic Violence". In Strang, Heather \& Braithwaite, John. Restorative Justice and Family Violence. Cambridge University Press. ISBN 9780521521659.

[26] Correctional Service of Canada. (1998). Performance report for the period ending March 31, 1998. Ottawa: Supply and Services Canada.

[27] Dambrun, M., \& Taylor, D. M. (2013). The Counterintuitive Association Between Life Satisfaction and Racism. SAGE Open, 3(3), 2158244013505756.

[28] Dambrun, M., Taylor, D. M., McDonald, D. A., Crush, J., \& Méot, A. (2006). The relative deprivationgratification continuum and the attitudes of South Africans toward immigrants: a test of the V-curve hypothesis. Journal of Personality and Social Psychology, 91(6), 1032.

[29] David R. Griffin, Spirituality and Society: Postmodern Visions, SUNY Press, 1988, ISBN 0-88706-853-7 Google Print, p.29

[30] Davies, Mathew (2011) The Reintegration of Elderly Prisoners: An Exploration of Services Provided in England and Wales.

[31] Davis, Angela (2011). Are Prisons Obsolete?. Seven Stories Press. ISBN 978-1-60980-104-5.

[32] Diana Kendall, Sociology In Our Times, Thomson Wadsworth, 2005, ISBN 0-534-64629-8 Google Print, p.530

[33] Durrant, Russil. "Collective violence: An evolutionary perspective". Aggression and Violent Behavior 16 (5): 428-436. doi:10.1016/j.avb.2011.04.014.

[34] Dye, M. H. (2010) 'Deprivation, Importation, and Prison Suicide: Combined Effects of

[35] Eagly \& Steffen (1986) Psychological Bulletin. "Gender and Aggressive Behavior: A Meta-analytic Review of the Social Psychological Literature" Volume 100, No 3. pp 323-325.

[36] Ellie L. Young, David A. Nelson, America B. Hottle, Brittney Warburton, and Bryan K. Young (2010) Relational Aggression Among Students Principal Leadership, October, copyright the National Association of Secondary School Principals.

[37] Engdahl, Sylvia (2010). Prisons. Farmington Hills: Greenhaven Press. .

[38] Eriksson, Torsten (1976). The reformers: an historical survey of pioneer experiments in the treatment of criminals. Elsevier Scientific Pub. Co. p. 147

[39] Establishment and Maintenance of Social Hierarchy in Laboratory Mice". Zhurnal Vysshei Nervnoi Delatelnosti Imeni I P Pavlova 56 (3): 412-419. PMID 16869278.

[40] Evidenced by a Prison Inmate Sample: Interrelationships and Consequences for

[41] Fazel, S.; Benning, R. \& Danesh, J. (2005) 'Suicides in Male Prisoners in England and

[42] Ferguson, C.J. (2010). "Blazing Angels or Resident Evil? Can violent video games be a force for good?" (PDF). Review of General Psychology 14 (2): 68-81. doi:10.1037/a0018941. Wikimedia Commons.

[43] Ferguson, C.J.; Beaver, K.M. (2009). "Natural Born Killers: The Genetic Origins of Extreme Violence" (PDF). Aggression and Violent Behavior 14 (5): 286-294. doi:10.1016/j.avb.2009.03.005

[44] Green, N. (1997). Okimah Ohci healing lodge. Let's Talk, 22(4), 11-12.

[45] Guilbaud, Fabrice. "To Challenge and Suffer: The Forms and Foundations of Working Inmates' Social Criticism (Sociétés Contemporaines 87 (2012))". academia.edu.

[46] Guilbaud, Fabrice. "Working in Prison: Time as Experienced by Inmate-Workers (Revue française de sociologie 51.5 (2010): 41-68)". jstor.org.

[47] Haley, H. J. (1984). Does the law need to know the effects of imprisonment? Canadian Journal of Criminology, 26, 479-491.

[48] Hall, D. Y. (1993). Eighth Amendment, Prison Conditions and Social Context, The. Mo. L. Rev., 58, 207.

[49] Hames-Garcia, Michael Roy (2004). "Towards a Critical Theory of Justice". Fugitive Thought: Prison Movements, Race, and the Meaning of Justice. University of Minnesota Press. p. 3. ISBN 9780816643141.

[50] Handbook of basic principles and promising practices on Alternatives to Imprisonment (PDF). United Nations. April 2007. ISBN 978-92-1-148220-1.

[51] Hanser, Robert D. (2002) Inmate Suicide in Prisons: An Analysis of Legal Liability under 42 USC Sections 1983. The Prison Journal, 82 (4) 459-477.

[52] Hanser, Robert D. (2012). Introduction to Corrections. SAGE. p. 199. ISBN 978-1-4129-7566-7.

[53] Hanser, Robert D. (2012). Introduction to Corrections. SAGE. p. 200. ISBN 978-1-4129-7566-7.

[54] Hanser, Robert D. (2012). Introduction to Corrections. SAGE. pp. 193-195. ISBN 978-1-4129-7566-7. 
[55] Hawley, P.; Vaughn, B. (2003). "Aggression and adaptive function: The bright side to bad behavior" (PDF). Merrill-Palmer Quarterly 49 (3): 239-242. doi:

[56] Iain Walker, Heather J. Smith, Relative Deprivation: Specification, Development, and Integration, Cambridge University Press, 2001, ISBN 0-521-80132-X, Google Books.

[57] Incarceration: Effects on Psychological Adjustment Following Release'. Criminal

[58] Innes, Martin (2003). "The Architecture of Social Control". Understanding Social Control: Crime and Social Order in Late Modernity. McGraw-Hill International. ISBN 9780335209408.

[59] Institutional Conditions and Inmate Composition'. Journal of Criminal Justice 38, 796-

[60] International Bar Association (2010) One in Five: The Crisis in Brazil's Prisons and CriminalJustice System..Retrieve from www.brazilink.org/tikitdownload-file .php.on 01-06 2012.

[61] Jacobson, Michael (2005). Downsizing Prisons: How to Reduce Crime and End Mass Incarceration. NYU Press. p. 6. ISBN 9780814742747.

[62] James, Joy, ed. (2003). Imprisoned Intellectuals: America's Political Prisoners Write on Life, Liberation, and Rebellion. Rowman \& Littlefield. pp. xi, xii, 11. ISBN 9780742520271.

[63] Jewkes, Yvonne \& Bennett, Jamie, eds. (2013). "Rehabilitation". Dictionary of Prisons and Punishment. Routledge. ISBN 9781134011902

[64] John Howard (1777), The State of the Prisons in England and Wales with an account of some foreign prisons.

[65] John Howard Society of Winnipeg. (1990). Prisoners: An historically disadvantaged group. Winnipeg: author

[66] Johnson, L. K.; Wiemer, D. F. (1982-09-01). "Nerol: An alarm substance of the stingless bee,Trigona fulviventris (Hymenoptera: Apidae)". Journal of Chemical Ecology 8 (9): 1167-1181. doi:10.1007/BF00990750. ISSN 0098-0331.

[67] Jonathan W. Daly, Autocracy under Siege: Security Police and Opposition in Russia, 1866-1905 (1998).

[68] Keeler, L.A (2007). "The differences in sport aggression, life aggression, and life assertion among adult male and female collision, contact, and non-contact sport athletes". Journal of Sport Behavior 30 (1): $57-$ 76.

[69] Keeley, L.H. (1996). War Before Civilization: The myth of the peaceful savage. New York: Oxford University Press.

[70] Knepper, Paul, and Per Jørgen Ystehede, eds., The Cesare Lombroso Handbook (2012)

[71] Laceulle, O.M., Jeronimus, B.F., Van Aken, M.A.G., Ormel, J. (2015). "Why Not Everyone Gets Their Fair Share of Stress: Adolescent's Perceived Relationship Affection Mediates Associations Between Temperament and Subsequent Stressful Social Events". European Journal of Personality 29 (2): 125. doi:10.1002/per.1989.

[72] Landsford, J.E (2012). "Boys' and girls' relational and physical aggression in nine countries". Aggressive Behavior 38 (4): 298-308. doi:10.1002/ab.21433.

[73] Law, Victoria (2009). Resistance Behind Bars: The Struggles of Incarcerated Women. Oakland: PM Press. p. 36.

[74] Lewis, W. David (2009). From Newgate to Dannemora: The Rise of the Penitentiary in New York, 17961848. Cornell University Press. p. 6. ISBN 9780801475481.

[75] Liebling, A. (1992) Suicide in Prisons. London: Routledge

[76] Lomas, W. (2009) Conflict, Violence, and Conflict Resolution in Hunting and Gathering Societies Totem: The University of Western Ontario Journal of Anthropology, Volume 17, Issue 1, Article 13.

[77] Lussier, Patrick; Raymond Corrado (20 September 2012). "Gender Differences in Physical Aggression and Associated Developmental Correlates in a Sample of Canadian Preschoolers $\uparrow "$. Behavioral Sciences and the Law 30 (5): 643-671. doi:10.1002/bsl.2035. Retrieved 6 December 2012.

[78] Maestripieri, D. (1992). "Functional Aspects of Maternal Aggression in Mammals". Canadian Journal of Zoology 70 (6): 1069-1077. doi:10.1139/z92-150.

[79] Maestripieri, D. (1992). "Functional Aspects of Maternal Aggression in Mammals". Canadian Journal of Zoology 70 (6): 1069-1077. doi:10.1139/z92-150.

[80] Maestripieri, D. (1992). "Functional Aspects of Maternal Aggression in Mammals". Canadian Journal of Zoology 70 (6): 1069-1077. doi:10.1139/z92-150.

[81] Malkin, I. (1995). The role of the law of negligence in preventing prisoners' exposure to HIV while in custody [On-line]. Available: http://www.aidslaw.ca/elements/B5MalkE.html

[82] Mason, Paul (2013). "Abolitionism". In Jewkes, Yvonne \& Bennett, Jamie. Dictionary of Prisons and Punishment. Routledge. ISBN 9781134011902. 
[83] McCall, Grant S.; Shields, Nancy. "Examining the evidence from small-scale societies and early prehistory and implications for modern theories of aggression and violence". Aggression and Violent Behavior 13 (1): 1-9. doi:10.1016/j.avb.2007.04.001.

[84] McClennan, Rebecca M. (2008). The Crisis of Imprisonment: Protest, Politics, and the Making of the American Penal State, 1776-1941. Cambridge University Press. pp. 33-36. ISBN 9781139467483.

[85] McCulloch, Jude \& George, Amanda (2008). "Naked Power: Strip Searching in Women's Prisons". In Scraton, Phil \& McCulloch, Jude. The Violence of Incarceration. Taylor \& Francis. ISBN 978-0-20389291-6.

[86] McDonald, Melissa M.; Navarrete, Carlos David; Vugt, Mark Van (2012-03-05). "Evolution and the psychology of intergroup conflict: the male warrior hypothesis". Philosophical

[87] McDonald, Melissa M.; Navarrete, Carlos David; Vugt, Mark Van (2012-03-05). "Evolution and the psychology of intergroup conflict: the male warrior hypothesis". Philosophical Transactions of the Royal Society of London B: Biological Sciences 367 (1589): 670-679. doi:10.1098/rstb.2011.0301. ISSN 09628436. PMC 3260849. PMID 22271783.

[88] McElliskem, Joseph E. (2004). "Affective and Predatory Violence: a Bimodal Classification System of Human Aggression and Violence" (PDF). Aggression \& Violent Behavior 10 (1): 1-3

[89] O'grady, William (2011). Crime in Canadian Context- Debates and Controversies. Don Mills, Ontario: Oxford University Press. pp. 218-220.

[90] Orange, Richard (11 November 2013). "Sweden closes four prisons as number of inmates plummets". The Guardian.

[91] Parolin, Cristina (2010). Radical Spaces: Venues of Popular Politics in London, 1790 - C. 1845. ANU Press. p. 58. ISBN 9781921862007. Architectural innovation lay at the heart of eighteenth-century prison reform and one of its master thinkers was Jeremy Bentham.

[92] Pelaez, Vicky (2008). "The prison industry in the United States: big business or a new form of slavery?". Global Research.

[93] Perusse, D. \& Gendreau, P. 'Genetics and the Development of Aggression' in Developmental Origins of Aggression, 2005, The Guilford Press.

[94] Peter Townsend, Poverty in the United Kingdom : A Survey of household resources and standards of living, Penguin Books, 1979, ISBN 0-520-039769.

[95] Petersilia, J. (2008). California's correctional paradox of excess and deprivation. Crime and justice, 37(1), 207-278.

[96] Prison Progamming'. The Prison Journal 77 (3): 259-280

[97] Prison Research Education Action (2005). "Demythologizing Our Views of Prison". Instead of Prisons: A Handbook for Abolitionists. Critical Resistance. ISBN 9780976707011.

[98] Psychology- The Science Of Behaviour, pg 420, Neil R Clarkson (4th Edition).

[99] Ramírez, JM; Andreu, JM (2006). "Aggression, and some related psychological constructs (anger, hostility, and impulsivity); some comments from a research project" (PDF). Neuroscience and biobehavioral reviews 30 (3): 276-91. doi:10.1016/j.neubiorev.2005.04.015. PMID 16081158.

[100] Robins, Simon (2009) Improving Africa's Prisons. Policy Brief Number 09, September. Retrieved from www.issafrican.org.on 01/06/2012.

[101] Ross Jeffrey Ian (2012)., "The Invention of the American Supermax Prison". In Jeffrey Ian Ross. The Globalization of Supermax Prisons. Rutgers University Press. ISBN 978-0-8135-5742-7.

[102] Roth, Michael P. (2006). Prisons and Prison Systems: A Global Encyclopedia. Greenwood Publishing. p. xxvi. ISBN 9780313328565.

[103] Sabbath M. J., \& Cowles, E. L. (1992). Problems associated with long term incarceration. Forum on Corrections Research, 4(2), 9-11.

[104] Santos, M. (1995). Facing long-term imprisonment. In Flanagan, T. (Ed.), Long-term imprisonment: Policy, science and correctional practice (pp. 36-40). London: Sage Publications.

[105] Schechter DS, Gross A, Willheim E, McCaw J, Turner JB, Myers MM, Zeanah CH, Gleason MM (2009). Is maternal PTSD associated with greater exposure of very young children to violent media? Journal of Traumatic Stress. 22(6), 658-662.

[106] Schellenberg, R. (2000). "Aggressive personality: When does it develop and why?". Virginia Counselors Journal 26: 67-76.

[107] Schmitt, J., Warner, K., \& Gupta, S. (2010). The high budgetary cost of incarceration. Washington, DC: Center for Economic and Policy Research. http://www. cepr. net/documents/publications/incarceration2010-06. pdf.

[108] Senior, Jane (2012). "Healthcare". In Jewkes, Yvonne \& Johnston, Helen. Handbook on Prisons. Routledge. ISBN 978-1-136-30830-7. 
[109] Shalev, Sharon (2013). Supermax: Controlling Risk Through Solitary Confinement. Routledge. p. 88. ISBN 978-1-134-02667-8.

[110] Shalev, Sharon (2013). Supermax: Controlling Risk Through Solitary Confinement. Routledge. p. 101. ISBN 978-1-134-02667-8.

[111] Taylor CA, Manganello JA, Lee SJ, Rice JC (May 2010). "Mothers' spanking of 3-year-old children and subsequent risk of children's aggressive behavior". Pediatrics 125 (5): e1057-65. doi:10.1542/peds.20092678. PMID 20385647.

[112] Toch, H. (1977) Living in Prison: The Ecology of Survival. New York: Free Press.

[113] Tomlins, C. (2001). The legal cartography of colonization, the legal polyphony of settlement: English intrusions on the American mainland in the seventeenth century. Law \& Social Inquiry, 26(2), 315-372.

[114] Towl, G. J. (2003) 'Suicide in Prisons: Reflections on Research and Practice'. The

[115] Transactions of the Royal Society of London B: Biological Sciences 367 (1589): 670-679. doi:10.1098/rstb.2011.0301. ISSN 0962-8436. PMC 3260849. PMID 22271783.

[116] Tremblay, R.E. (2000). "The development of aggressive behaviour during childhood: What have we learned in the past century". International Journal of Behavioral Development 24 (2): 129-141. doi:10.1080/016502500383232.

[117] Trend toward solitary confinement worries experts. CNN Interactive. (1998, January 9) [On-line]. Available: http://cnn.com/US/9801/09/solitary.confinement/

[118] Turning, Patricia (2012). "Competition for the Prisoner's Body: Wardens and Jailers in FourteenthCentury Southern France". In Classen, Albrecht \& Scarborough, Connie. Crime and Punishment in the Middle Ages and Early Modern Age: Mental-Historical Investigations of Basic Human Problems and Social Responses. Walter de Gruyter. p. 285. ISBN 978-3-11-029458-3.

[119] UNESCO Prize for Peace Education, (1989), Retrieved:http://www.demilitarisation.org/IMG/article_PDF/Seville-Statement-UNESCO-1989_a143.pdf .Vogel, Brenda (2009). The Prison Library Primer: A Program for the Twenty-First Century. Scarecrow Press. p. 176. ISBN 9780810867437.

[120] Voglis, Polymeris (2002). "Introduction". Becoming a Subject: Political Prisoners During the Greek Civil War. Berghahn Books. ISBN 9781571813084.

[121] Vugt, Mark van (2006). "Gender Differences in Cooperation and Competition: The Male-Warrior Hypothesis" (PDF). Psychological Science 18: 19-23. doi:10.1111/j.1467-9280.2007.01842.x.

[122] Wales, 1978-2003'. The Lancet 366, 1301-1302.

[123] Walmsley, Roy (October 2010). "World Prison Population List (Ninth Edition)" (PDF). Retrieved 201212-17.

[124] Walter Garrison Runciman, Relative deprivation and social justice : a study of attitudes to social inequality in twentieth-century England, University of California Press, 1966.

[125] Weekes, J. R. (1992). Long-term offenders in Canada. Forum for Corrections Research, 4(2), 3-7.

[126] Wehr, Kevin \& Aseltine, Elyshia (2013). Beyond the Prison Industrial Complex: Crime and Incarceration in the 21st Century. Routledge. p. 28. ISBN 9781135093129.

[127] Welch, Michael (2004). "A Social History of Punishment and Corrections". Corrections: A Critical Approach. McGraw-Hill. ISBN 0-07-281723-2.

[128] Welch, Michael (2004). "Juveniles in Corrections". Corrections: A Critical Approach. McGraw-Hill. ISBN 0-07-281723-2.

[129] West, Charles E. (1895). Horrors of the prison ships: Dr. West's description of the wallabout floating dungeons, how captive patriots fared. Eagle Book Printing Department.

[130] Wiliams P;Walton K and Hannan - Jones M. (2009) Prison Food Service in Australia Systems, Menus and Inmates Attitudes.

[131] Zingraff, M. T. (1975). Prisonization as an inhibitor of effective re-socialization. Criminology, 13, 366381.

[132] Zlotnick, Caron. "Posttraumatic Stress Disorder (PTSD), PTSD Comorbidity, and Childhood Abuse among Incarcerated Women." Journal of Nervous \& Mental Disease 185.12 (1997): 761-63. Lippincott Williams \& Wilkins. Web. 13 Mar. 2012. 